UDK: 330.322 .1

POSLOVNA EKONOMIJA BUSINESS ECONOMICS Godina XI

Originalni naučni rad Broj I

Str $1-29$

doi:10.5937/poseko11-13332

PhD Gurdip S. Batra, ${ }^{1}$ Professor of Management, Dean and Head Faculty of Business Studies, Punjabi University, Patiala, Punjab, India

Tamana Anand, ${ }^{2}$ PhD student

Uttarakhand Technical University, Dehradun, India

\title{
IMPACT OF FDI IN ORGANISED RETAILING IN MALAYSIA: STUDY OF DIFFERENT INTERMEDIARIES
}

\begin{abstract}
This study examines the impact of Foreign Direct Investment (FDI) in organised retailing in Malaysia with reference to consumers and retailers. Findings reveal that FDI in organised retailing in food and grocery and apparel \& clothing is related with product \& store attributes, economic, social, technological benefits to both consumers and retailers. Malaysian consumers' are conscious of quality and looking for diverse product range so will prefer organised retail format for shopping. Consumers are aware of economic, social, technological benefits of FDI in organised retailing. It is also suggested that small retailers should focus on marketing strategies such as loyalty programmes, free gifts, store image and festival offers to attract customers as compare to organised retailers. Additionally, the paper empirically examine that foreign retailers can help small traditional retailers by trainings, new market opportunities, quality assurance, technology support, contract farming, efficient marketing chain, better packaging and e-commerce. They can also assist small farmers in forming the capacity to pursue successful strategies of portfolios of participation in the various market channels.
\end{abstract}

${ }^{1}$ batra.gurdip@gmail.com

2 sehgal_tamana@yahoo.com 
Keywords: Foreign Direct Investment FDI, Organised Retailing,

Economic benefits, Social benefits, Technological benefits

\section{INTRODUCTION}

\section{Retailing}

The retailing has been explained as "sale of goods or commodities in small quantities directly to consumers" (Panneerselvam, 2012). The retail industry is divided into organised and unorganised sectors. Organised retailing refers to "trading activities undertaken by licensed retailers who are registered for sales tax, income tax, etc". These include the privately owned large retail businesses and big corporates into the business of hypermarkets and retail chains (Ramakrishnan, 2010). Unorganised retailing, on the other hand, refers to the "traditional formats of low-cost retailing like local kirana shops, general stores, paan/beedi shops, convenience stores, hand cart and pavement vendors, etc."(Ramakrishnan, 2010). These shops are small in size (less than 500 square feet in area) and are largely owner- managed with minimal labour help, and stock a very limited number of items (Zameer \& Mukherjee, 2011).

\section{World Scenario}

During the last two decades there has been a significant growth in the internationalization of the services sector due to tremendous progress made in the development of telecommunications and information technology. Retail sector services has been grew drastically from last decade. The globalization of the retailing industry has helped many retail multinationals mostly in food \& grocery and general items business like Wal-Mart, IKEA, Courts Mammoth, Carrefour, Tesco, Ahold, etc. to start their business in various developed and emerging markets (AT Kearney, 2005; CPAS study). These trends have been grown by push and pull factors. Due to mature markets, high competition and low profitability (market saturation), low growth, domestic regulation in developed countries has encouraged the expansion of major retailers into the developing and emerging markets (Halepete et.al, 2008). The pull factors are growing business opportunities, increase in urbanization, high population growth, rising incomes, westernization of lifestyles, increasing demand and the relaxation of restrictive trade policies in developing countries (Reardon \& Minten, 2011). From Table 1(attached in appendix) The Global Retail Development Index (GRDI) ranks the top developing countries for retail investment based on several macroeconomic and retail- specific 
variables. Malaysia scored (52.8) as compare to other countries. If we see results in table $2 \& 3$ (attached in appendix) Asian countries like China, Singapore, Thailand, Malaysia are compared on the basis of population, GDP , inflation, retail sales and Malaysia's growth

has been progressive with GDP 5.6 \% and China tops the chart with highest GDP of $7.7 \%$. Malaysia's GDP per capita has already higher than China and India. The famous tourist cities in South East Asia (Kuala Lumpur, Singapore, and Bangkok) are the ones considered best for retail business., these cities have lots of development in areas of airports, transit systems, public space etc. which are conducive for retail markets (Pramerica real estate investors report, 2013).

\section{Retailing in Malaysia}

Malaysia's retail industry has been progressed very well and modern retail formats like hypermarkets and supermarkets are favourite destination for consumers to buy foods and consumer goods. This development is fuelled by the globalisation process, in particular the foreign direct investment (FDI) policies of the Malaysian government (Abdullah 2011). Malaysia's population is relatively small but it is boosted by high capita income and a young population. In Malaysia, the structure of food retailing has changed dramatically over the last few decades as we can see that in previous years, the only retail formats were the traditional markets, grocery stores or mini markets but now modern retail formats has grabbed the consumer market share. Consumers purchase almost everything there including fresh fruit and vegetables, meat, chicken and fish, and other household supplies like dry food, bread, detergents, stationery and toys from organised retailers (Shamsudin and Selamat 2005). According to (Chamhuri and Batt 2010) modern retail dominates in urban centres, while traditional formats leads in rural areas. In food modern retailers are gaining a greater foothold, with a market share expected to reach 53 percent by 2020. (AT Keraney report).

The traditional market comprises of wet markets, fresh markets, night markets or farmer's markets and consumers still prefer to shop at these stores due to greater convenience. They are commonly found in all the cities, towns and villages in Malaysia. Organized retail in Malaysia is consists of department stores, supermarkets, mini markets, specialty shops, convenience stores, provision stores, pharmacies, medical halls, direct sale, wet market stalls to pavement shops and petrol kiosks (Seventh Malaysia Plan, 1996). 


\section{Growth Factors for Retail}

The growth of organized retailing in Malaysia is taking new heights and there are many factors responsible for making it to happen. Various parameters like economic growth, population changes, liberalization, FDI etc. are few of them.

\section{Consumers}

As the development of the food retail industry is robust so the behaviour of consumers in Malaysia has also been changing drastically. Several factors like increase in disposable income, urbanisation, awareness of food safety and food quality issues, and changes in diet are influencing the customers purchase intention (Wong 2007). The stiff competition for consumers among the major retail players has intensified due to the fact that Malaysian shoppers have become more sophisticated and demanding in their shopping experiences.

\section{Government Initiatives}

The Malaysian government has made special initiatives for bumiputera graduates to become more entrepreneurial and get involved in retailing business. This will help them to become more self-sufficient and nondependent on public sectors for employment. The successful bumiputera entrepreneurs can help the government to bring positive changes in the retail industry and take it to the new dimensions, these bumiputera retailer originates from or rural based trading enterprise (Crewe and Forster 1993; Tingii et al 2012).Other government initiatives in Malaysia are related to foreign hypermarkets to develop local small scale industries in the development and growth of the domestic suppliers via backward linkages. These foreign hypermarkets will help smaller industries, retailers, farmers etc. with providing linkages of product supply, informational linkages, assistance with inventory management, technical support and quality assurance and procurement system. There will be many benefits for small scale industries in terms of an increase in sales, consistent year-round business, reliable payment, expansion into international market, improvement of product quality, and increased profit. Also there will be progress in on-time delivery, pricing, product quality and payment systems.

In Malaysia, supervision of the wholesale and retail sectors comes under the Ministry of Domestic trade and Consumer Affairs (MDTCA). Set up in 1995, the committees on wholesale and retail trade regulates and supervises the industry, including foreign involvements in the sector for example policies like approval for wholesale or retail operations locally, open and relocate branches. Government have clear cut property regulations for foreign investors. And they have follow the guidelines made by the foreign Investment 
Committee (FIC) for the purchase of commercial units (Mutebi 2007) very strictly. Malaysia introduced a law prohibiting new large format retail establishments from being built within $3.5 \mathrm{~km}$ radius of housing areas or city centers. There are special rules for new applicants who wish to open large format retail outlets in Malaysia, they have to submit their applications to build such outlets two years in advance. New guidelines that lengthened the approval time for developers seeking to build such stores in any other provincial urban areas from four months to 2 years (Mutebi 2007).

\section{Major retailers in Malaysia}

The major food retail operators include:

- The Cold Storage Group which is the largest food retailer in Malaysia in terms of sales as well as number of retail outlets.

- Tesco Malaysia which is one of the largest food retailer in Malaysia in terms of sales. It operates Tesco and Tesco Extra stores in the major cities in Malaysia.

- AEON Malaysia which operates the Aeon and Aeon Big Stores nationwide. This is the largest high end department store chain.

- The Store is also popular food retailer in Malaysia.

- Other popular Malaysian owned premium supermarkets are Jaya Grocer (the fastest growing local chain) \& Hock Choon, Village Grocer, Ampang Grocers, BIG (Bens Independent Grocer) and the latest addition, Sam's Groceria. These outlets target the middle to high income shoppers and more than $50 \%$ of their products are imported.

\section{LITERATURE REVIEW AND HYPOTHESIS DEVELOPMENT}

\section{Theoretical Background}

The present study understands holistic perspective of Malaysian retailing considering consumers and retailer's perspectives. This research identifies the consumers' behaviour towards emerging retail formats. It has also included the types of goods preferred for buying from emerging retail formats. The study takes into account the retailers' perspective as well by identifying the impact of foreign retailers on the business of small retailers. It has also studies marketing strategies adopted by small retailers to influencing consumers' purchase preferences from unorganized retail to counter the impact of FDI. To present a holistic picture of retail scenario as shown in Figure 1(attached in appendix) 


\section{FDI (Foreign Direct Investment) in organised retailing}

Globalisation has helped many foreign players like IKEA and Marks \& Spencer, hypermarkets like Tesco and Carrefour to venture in Malaysian market. Government is trying to encourage higher levels of spending by meeting rising consumer expectations. To achieve this, companies involved in retail in Malaysia will need to modernise and innovate, applying international retail best practices. In the hypermarket segment, the main players are foreign owned retailers such as Carefour (France), Makro (Holland), Aeon (Japan), Tesco (United Kingdom) and Giant (Hong Kong) which account for 46 per cent of the hypermarket sector (Economic Report 2015/2016). By 2020 there were around 1500 foreign supermarkets and hypermarkets spread around the country including the sub-urban areas in Kuala Lumpur and Selangor, and other states such as Perak, Johor, Negeri Sembilan, Melaka, Kedah, Sabah and Sarawak (Kaliappan et al 2009). The retailing industry is one of the biggest contributors towards Malaysia's gross domestic product (GDP) and also provides employment opportunities (Mui et al 2003). Weld Supermarket was the first modern retail format that was introduced in Malaysia in 1963 followed by other modern retailers (Kaliappan et al 2009). The first hypermarket that was introduced in Malaysia was Makro, in 1993 (Lee 2004).

The development of hypermarkets in Malaysia is phenomenal which is evident from the many hypermarkets and supermarkets mushrooming in this country from last decades (Abu 2004). Hypermarket chains are rapidly growing in Malaysia to meet the needs of more affluent consumers due to changes in society's educational levels and consumers' shopping behaviour. All hypermarkets offer soft lines (garments, clothes, carpets etc.), hard lines (electrical appliances, stationery), groceries and fresh food. The last could be one of the major income contributors for the hypermarket. According to strict government policies the hypermarket stores in Malaysia are and will located in the new housing estates and new townships only.

\section{Consumers}

In this new era there is major shift in consumers' socio-economic, demographic and geographical factors and these are the main drivers of growth of organised retail formats. Traditional small-scale retail outlets are failed to tap the needs and tastes of modern consumers. It is also very important for retailers to understand the need of customers and offer products and services according to changing consumer preferences and life style (Jhamb \& Kiran, 2012; Ghosh \& Tripathi, 2010). Consumers have changed from times, there is shift in consumers' socio-economic, demographic and geographical conditions which are the main reasons for change from traditional small-scale retail outlets to an organised retail formats who understands consumer's needs better. 


\section{Social Impact}

With the development of the food retail industry, these social factors like increase in personal disposable income, the need for convenience, greater awareness of food safety and food quality issue have emerged. Consumers' psychological factors are changing these days like values, activities, interests, opinions, motives and lifestyles and these changes have contributed to the growth of store format such as convenience stores, discount stores, super markets and hypermarkets (Prasad \& Aryasari, 2011). But on the other hand consumers also like shopping at traditional small retail shops which helps them to socialize with the retailers and other shoppers (Arivazhagan, Geetha \& Parthasarathy, 2012).

It has been observed that the modern retail sells food at relatively low prices as compare to traditional retailers. Modern retail also deliver processed products cheaper and also focus on offering branded and labelled products at good prices (Anand \& Nambiar, 2010).

\section{Product \& Store Attributes}

The preference of emerging retail formats like malls, speciality stores, discount stores, hyper/supermarkets, convenience stores and department stores are by consumers due to their special product and store attributes. Akram, Anwar \& Khan (2014) supported that consumers' choice of modern retail formats over traditional market stores is influenced by various factors like strategic location, ambience, variety, sales promotion schemes and instore services. The development of supermarkets and hypermarkets has benefited consumers by offerings more product choices and services at affordable prices, cleaner shopping environment, efficient use of technology, better choice, efficient logistics, improvement in quality, better packaging and Cleaner shopping environment becomes an attraction for modern customers (Zameer \& Mukherjee, 2011; Goel \& Dewan, 2011).

\section{Retailers}

Consumers' give importance to services, employee behaviour, credit policies, and social relationships while evaluating retail service quality, this are the positive sign for the small retailers. The ambience and infrastructure of malls, hypermarkets, and supermarkets may be superior to small retail outlets; however, consumers perceive small retail outlets to fulfil their hedonic and utilitarian shopping values. Shoppers may be attracted to the glamour of malls but for daily shopping needs but depend on small retail outlets.

\section{Economic Impact}

The globalisation process and FDI have brought important changes in the retail industry and helped in economic growth. New retail format 
companies have understood the negative impact on small retailers in terms of loss of livelihood so organized they are inviting small retailers to become franchises on a revenue sharing model (Singh et al., 2010). Large foreign retailers such as Tesco, Ahold and Carrefour prefers to procure 90-98 per cent of their product supplies from small companies within the host country. The gainers from these strategies are domestic suppliers and SMEs producing consumer goods and services. They are also get advantage in terms of exporting their supplies through the global network of the foreign retailers. Domestic suppliers and farmers have to follow strict rules to improve the quality and safety of their products as they have to meet the standards and requirements set by foreign retailers (Goswami \& Mishra, 2009; Chanderskehar, 2009). The development of supermarkets and hypermarkets has brought new dimensions to the Agri-food supply chain management. These include efficient logistics and better centralised collection and distribution centres, together with the emphasis on better quality products.

\section{Technological Impact}

Informational linkages: Foreign hypermarkets have extensive knowledge of international and domestic market potential in terms of price trends and on the sources of products, they are able to inform domestic suppliers about new market developments or their future requirements to ensure that there is a balance between the capacities of suppliers with the requirements of foreign hypermarkets (Sahay \& Mohan, 2006).

New Technologies: There are new technologies like vendor managed inventory (VMI), radio frequency identification (RFID), collaborative planning and forecasting (CPFR) adopted by foreign retailers (Seetharaman et al., 2013). Modern technology will help hypermarkets to order directly from the supplier when the cashier scans the bar code of a product. Above technologies have helped big retailers to be efficient and productive. They can always pass the benefits from these new systems to small retailers and farmers.

According to government departments FAMA, hypermarkets require that local farmers strictly follow good agricultural practices (GAP) and the Malaysian Farm Accreditation Scheme (SALM). This accreditation is based on Euro-Retailer Produce Working Group GAP standards, contracted farmers are required to follow written product specifications agreed between FAMA and the hypermarkets. If we analyse Tesco example in Malaysia, it has a technical consultant to audit the vegetable suppliers, to identify the deficiencies in the quality of supplied vegetables, and to recommend a number of initiatives for FAMA to take in order to meet the requirements. Tesco Company tries to involve many local entrepreneurs to get involved in the programme which helps economy to grow. The main objectives of these initiatives are to increase the production of food through systematic approach; 
to ensure guaranteed market outlets for farmers; to ensure a consistent supply of quality produce; to ensure transfer of technology and implementation of a quality control programme; and to build successful agri-business entrepreneurs among contract farmers. FAMA on the other hand, provides marketing support services assistance to local farmers and SMEs to promote local food and agricultural products in both the domestic and international markets (Kaliappan et al 2009).

\section{Marketing Strategy}

Consumers' choice is the critical component for success for retailers. It is not easy to satisfy the consumers as they want high quality merchandise at low price. So it is important for retailers to focus upon the attractive marketing strategies to satisfy the consumers' needs. Retail marketing strategies are playing significant role in the growth of organized retail sector. Retailers are opting for various marketing strategies to attract consumers to buy from emerging retail formats. When they go to make purchases from the local store they do not have any expectation about its ambience or organised layout. To target this age group, the retailers must increase their product assortment, add more product lines and brands, and make new products easily available. They prefer to stock products which readily sell and are items of popular demand. Increasing product variety would enable them to get consumer footfall and help them in improving service quality perceptions (Khare A, 2013).

\section{EXPERIMENTAL (RESEARCH)}

Research Hypothesises:

H1 Consumers in Malaysia prefer organised retail for buying food (grocery) and apparel (clothing)

H2 Consumers' preferences towards organized retail formats are influenced by its product and store attributes in Malaysia

H3 FDI in Organized retail in Malaysia has bought economic, social and technological benefits to consumers

H4 FDI in Organized retail has no negative impact on small retailers in Malaysia

H5 FDI in organized retailing in Malaysia has bought economic and technological benefits to small retailers

\section{Sample Size}

The study selected a 250 consumers and 100 retailers for collecting data from the capital of Malaysia Kualalumpur. 


\section{RESULTS}

\section{Consumers' Analysis}

The demographic results reflects the basic characteristics of the consumer households surveyed. Out of the 203 respondents surveyed, 33 per cent were male and 67 percent were female. Age composition of the sampled respondents indicates that the surveyed group has major categories of consumers as 48 per cent of the respondents were between 30 to 39 years of age. Sample households falling between the monthly household incomes above RM 6000 with had a dominant share of 46 per cent, followed by income group of RM. 4001-6000 with 24 per cent share. Educational profile of the respondents shows that most of them have postgraduate or graduate level qualifications. Only 10 per cent of the respondents are from the undergraduate level. Most of the sample consumers, i.e., 41 percent belong to homemaker followed by professional and business.

\section{Preference of retail formats and its attributes}

The study uses descriptive analysis for finding out consumer preference of retail formats for buying fresh groceries, branded \& dry groceries and apparel \& clothing. Traditional market, mom n pop store, convenience stores, hypermarkets/supermarkets, speciality stores have been considered for the study. The related hypothesis is:

H1: Consumers in Malaysia prefer organised retail for buying food (grocery) and apparel (clothing)

The results shows that; consumers prefers hypermarkets for purchase of fresh groceries like fruits, vegetables, and meat \& dairy products. After hypermarkets most of respondent's preference is convenience store. Consumers do prefer mom $\mathrm{n}$ pop stores and traditional market due to its convenient location and operating hours. Findings are supported by earlier researchers like Aggarwal (2007).

The results shows that; consumers prefers convenience stores for purchase of branded \& dry groceries like personal care \& utilities, grains \& cereals. After convenience stores most of respondent's preference is mom $n$ pop store. Consumers do prefer hypermarkets due to wide variety of brands available and online shopping facility. Findings are supported by earlier researchers like Aggarwal (2007).

The results shows that; consumers prefers speciality stores for buying apparel $\mathrm{n}$ clothing. Second most preference are hypermarkets and then departmental stores due to good variety of apparel brands. Least preferred 
option is traditional market. Findings are supported by earlier researchers like Aggarwal (2007).

From these results, it is evident that the consumer prefer organised retail for buying fresh \& branded groceries and also apparel \& clothing. Hence H1 has been accepted as these items score have higher loading value in factor analysis. These results are corroborated by earlier studies, like Herpen and Pieters (2000), Popkowski et al. (2001) also supported similar results.

\section{Organised retail product and store attributes for food \& groceries}

The study tries to identify the important product and store attributes of organised retail for food \& groceries that influence consumers to shop from emerging retail formats. Factor analysis on product attributes helped in classifying items into important factors. The related hypothesis is:

$\mathrm{H} 2$ : Consumers' preferences towards organized retail formats are influenced by its product and store attributes in Malaysia

The study tries to identify the important product and store attributes that influence consumers to shop from emerging retail formats. Factor analysis on product and store attributes helped in classifying items into three factors namely,

1. Core product attributes- Most important attributes

2. Secondary product attributes- second most important factors

3. Supplementary product attributes- least important attributes

Product Attributes: Credit Facility (.733), proper display (.655) and proper packaging (.645) are the most important attributes of organised retail. Consumers will give importance to above factors while shopping in organised retail. Exchange facilities (.589), Variety of Brands (.584), competitive prices (.578) are emerged as the second important factor. Consumers will also keep in mind that credit facility and exchange facility will give lot of convenience to them

Store Attributes: Loyalty programs (.668), trained sales personnel (.660), cleanliness of store (.632), children play area (.616) and complete security (.611), availability of trolleys (.609) are the most important store attributes of organised retail for consumers. Parking facility (.580), air conditioned (.564), Instore promotions (.525) are the second most important factors.

From these results, it is evident that the product attributes like credit facility, proper display and proper packaging and store attributes like loyalty programs, trained sales personnel, cleanliness and availability of trolleys may be more important indicators of shopping from the emerging retail formats. These results are corroborated by earlier studies, like Herpen and Pieters (2000), Popkowski et al. (2001), Gupta (2004). 


\section{Organised retail product and store attributes for apparel \& clothing}

The study tries to identify the important product and store attributes of organised retail for apparel \& clothing that influence consumers to shop from emerging retail formats. Factor analysis on product attributes helped in classifying items into important factors namely,

The study tries to identify the important product and store attributes that influence consumers to shop from emerging retail formats. Factor analysis on product and store attributes helped in classifying items into three factors namely,

1. Core product attributes- Most important attributes

2. Secondary product attributes- second most important factors

3. Supplementary product attributes- least important attributes

Product Attributes: Easy availability of brands (.781), variety of brands (.771) and proper display (.708) are the most important attributes of organised retail. Consumers will give importance to above factors while shopping apparel \& clothing in organised retail. Price (.644), exchange facilities (.635) and quality \& design (.604) are emerged as the second important factor. Consumers will also keep in mind that credit facility and exchange facility will give lot of convenience to them. Proper packaging plays very important role in attracting consumers towards new retail formats.

Store Attributes: Parking facility (.781), pleasant ambience (.730), complete security (.718) and dressing rooms (.708) are the most important store attributes for apparel shopping.

Convenient location (.691), customer service (.672), helpful staff (.648), children play area (.639), in store promotions (.631) are secondary factors which customers will prefer.

From these results, it is evident that the product attributes like easy availability of brands, variety of brands and improved quality \& design and store attributes like better location, children play area and dressing rooms may be more important indicators of shopping from the emerging retail formats. These results are corroborated by earlier studies, like Gupta (2004), Urbonavicius and Ivanauskas (2005) and Jackson (2006) also supported similar results. Hence $H 2$ : Consumers' preferences towards organized retail formats are influenced by its product and store attributes in India \& Malaysia is accepted.

\section{Unorganised Retail attributes}

The study tries to identify the important product and store attributes of unorganised retail for food \& groceries and apparel that influence consumers 
to shop from emerging retail formats. Factor analysis on product attributes helped in classifying items into important factors namely,

Personal relationship with retailers (.814), returns goods easily (.779), home delivery (.771) are some of the attributes which consumers like to shop from unorganised retail. Loyalty to same vendor (.754) has much importance to customers if they want to shop from traditional market.

\section{Product-Wise Shopping Preferences from Different Retail Formats}

This section covers the consumers' preferences of shopping fresh groceries, personal care \& utilities and apparel $\mathrm{n}$ clothing from different retail formats. On the basis of consumers' preferences, the detailed analyses have been done on product wise-preferences of shopping and convenience goods.

Organised retail: Results depicted highlights the consumers' preferences of shopping of apparel $n$ clothing (rank 1) from organised retail. The results from the above table depict that consumers prefer to purchase personal care \& utilities(rank 2) from emerging retail formats; this was followed fresh food \& grocery(rank 3) are the least preferred shopping products purchased by consumers from malls. Hence following hypothesis is accepted.

H1: Consumers in Malaysia prefer organised retail for buying food (grocery) and apparel (clothing)

Unorganised retail: Results depicted highlights the consumer's preferences of shopping fresh food \& groceries (rank 1) from traditional market. Second preference of product is personal care \& utility (rank 2) and followed by apparel $\mathrm{n}$ clothing.

\section{Purpose to Visit Organized Retail in Malaysia and Preferences of Retailers}

It is clear from result depicted that consumers visit emerging retail formats only for shopping as it has the highest rank. Second purpose is entertainment while doing shopping and it is followed by window shopping with the third rank.

\section{Foreign Retailers}

From results we can conclude that all kind of supermarkets/hypermarkets are preferred by Malaysian consumer according to their need and location. Cold Storage, village Grocer, Aeon, Tesco are quite famous among consumers. 


\section{Foreign retailers as compare to traditional retailers}

From the comparison services of traditional market as compare to foreign retailers, results will be in favour of FDI as $98 \%$ of respondents gave their choice to foreign retail and only $2 \%$ preferred traditional markets for shopping.

\section{Malaysians Organised Retailers}

From the results we can conclude that Parkson (37\%) is most preferred Malaysian retailer among consumers. Second most famous retailer is Metrojaya (36\%) followed by Hero Hypermart (8\%). Jaya Grocer, KK supermart, Mydin are other retailers which are quite preferred by customers according to their needs.

\section{Malaysian organised retailers as compare to foreign retailers}

From the comparison services or organised Malaysian retailers as compare to foreign retailers, results will be in favour of FDI in new retail formats as $86 \%$ of respondents gave their choice to foreign retailers and only $14 \%$ preferred local retailers for shopping.

\section{FDI in Organised Retail in Malaysia}

In this section we have asked respondents to evaluate the benefits of foreign direct investment in retailing in Malaysia. We have asked questions related to economic and social factors to get to know that how consumers think about entering of foreign retailers in Malaysian market. Hence related hypothesis is:

H 3- FDI in Organized retail in Malaysia has bought economic, social and technological benefits to consumers

Results shows that consumers are aware about economic benefits of organised retail for the country. Consumers have given importance to factor 'Employment' have highest coefficients (.723) followed by 'Economic Growth' (.704) and then 'Growth of real estate' (.627). Hence Hypothesis H3 is accepted.

Results shows that consumers are aware about social benefits of organised retail for the country. Consumers have given importance to factor 'Care about labour laws \& human rights' (.743) have highest coefficients followed by 'Care about environmental safety' (.707) and then 'Care about local culture' (.662). Hence Hypothesis H3 is accepted. 


\section{E-Retailing}

In this section we have asked consumers preference of organised retail for online shopping. They have asked questions related to various attributes of e-retailing.

\section{Organised retail for online shopping}

Most of the respondents (75\%) have shown interest in e-retailing. Among population $25 \%$ of respondents have said 'No' to this question. These respondents prefer organised retail due to the shopping online facility provided by organised retailers.

From results respondents were asked about importance of various attributes of e-retailing. Quality of product (.786) have highest coefficient that means this is the most important factor. Online security (.747), Ease of navigation (.728) are other important factors.

\section{Regression Analysis}

To know the impact of Foreign direct investment in organised retailing, we have used organised retail as a dependent variable and using other five factors namely product attributes, store attributes, economic, social \& technological as an independent variables, step-wise regression analysis has been used to find out the important predictors of the model. The results again support that the important factors like product attributes, store attributes, and social factors are the main advantages of organised retail. We have conducted regression analysis for two products- groceries \& apparel. Results has been shown in table 4,5,6,7 (attached in appendix):

\section{Regression results for fresh \& branded groceries}

FDI in Organised Retailing $=0.345^{*}$ Product attributes+ 0.154* Store Attributes $+0.113^{*}$ Economic factors+ $0.084^{*}$ Social Factors+ 0.232* Eretailing

The results of the step-wise regression analysis depict that important factors of the model are:

Product attributes, store attributes and e-retailing. These three variables explain 76.7 percent of variation. FDI in organised retail are positively related to product attributes $(.345)$, store attributes $(0.154)$, economic factors $(0,113)$, social factors (0.084) and e-retailing (0.232). ANOVA results depict that $\mathrm{F}=$ $55.842,(\mathrm{p}<.001)$ is significant and thus the model is good. 
Regression Analysis for Apparel \& clothing

FDI in Organised Retailing $=-0.071 *$ Product attributes $+0.232 *$ Store Attributes $+0.179 *$ Economic factors $+0.212 *$ Social Factors+ 0.213* Eretailing

The results of the step-wise regression analysis (table 8,9,10,11 (attached in appendix)) depict that important factors of the model are:

Store attributes, economic factors, e-retailing and social factors. These four variables explain 63.1 percent of variation. FDI in organised retail are positively related to store attributes (.232), economic factors (0.179), social factors $(0.212)$ and e-retailing $(0.213)$. On the other hand product attributes factor is negatively related to FDI with coefficient $(-0.071)$

ANOVA results depict that $\mathrm{F}=26.025,(\mathrm{p}<.001)$ is significant and thus the model is good.

\section{Retailers- Malaysia}

\section{Profile of retailers}

Most of the retailers were male $64 \%$ and only $36 \%$ were females. Small businesses is dominated by males. Most of the small retailers with percentage of $72 \%$ are either graduate or undergraduate in terms of education. Only $13 \%$ are having higher education with post graduate degrees. In retail formats maximum numbers are mini markets which are situated in neighbourhood.

\section{Retailer Marketing Strategies}

Based upon the literature review, thirteen retail marketing strategies have been taken up for analysis. These strategies are: advertisement, competitive pricing, free gifts, discounting options, loyalty programs, attractive merchandising, private label branding, customer segmentation, customized technology adoption, better internal environment, after sale services, store image/positioning, festival offers, understanding the customer, public relation and e-retailing.

From results all strategies are very important as all have higher coefficients $(>0.8)$ especially loyalty programmes, free gifts, store image and festival offers have highest factor loading. From above results we can conclude that if small retailer follows above marketing strategies then they can attract customers as compare to organised retail.

\section{Malaysian Organised Retail Chain}

In small retailers have been asked about awareness of Malaysian organised retail chains. The results are like this: Most famous is Mydin with $43 \%$, then Jaya grocer $40 \%$ and KK supermart. 


\section{Awareness of FDI \& Foreign Retailers}

When retailers have asked regarding awareness of FDI \& Foreign retailers then most of them said "YES". Most famous retailing chains are Aeon, Tesco, Giant and Aeon Big.

\section{Impact of Modern Retailing}

It is very important to take opinion from small retailers on impact of modern retailing on their business. We have asked five questions related to business affected by big companies. From results retailers have given positive feedback on organised retailing. They think that there will be increase in jobs if foreign retailers enter India. Second most important factor is increase in standard of living.

\section{Prospects of Organised retail}

Retailers have been asked about prospects of organised retail. After asking ten questions related to advantages of FDI in retailing, we can see from below chart that retailers have given positive feedback, most important benefit is to farmers, and growing awareness of consumers.

\section{Help to small retailers}

Small retailers have been asked about the support provided by big retailers to them so that there should not be any impact on their business. Support in terms of trainings, new market opportunities, quality assurance, technology support, contract farming, efficient marketing chain, better packaging and e-commerce. From factor analysis assistance in inventory management, improvement in quality, technological support, systematic marketing are the most important support small retailers have felt. Second important factor are shorter marketing chains, cleaner shopping environment, fair pricing, and cheaper imported agricultural produce.

\section{Problems with Foreign Retailers}

Some retailers still feel that big foreign retailers will create problems in their business and we have tried to ask small retailers to give their opinion on problems faced by them. We have asked six questions .Late payment and 
difficulty in consistent supply are the two common problems faced by small retailers.

\section{E-Retailing}

We have asked retailers about awareness of e-retailing and will they consider to start their website for online shopping.69\% retailers know about e-retailing and $93 \%$ retailers want to start e-commerce to attract customers.

\section{Start of e-commerce}

Retailers have given importance to all the e-commerce factors like user friendly, easy availability of information, ease of navigation, speed, online security, privacy policy, quality of product, attractive pricing, ease of payment.

\section{Regression Analysis}

To know the impact of Foreign direct investment in organised retailing on small retailers, we have used preference of unorganised retail by consumer and retailer performance as a dependent variable and using other five factors namely marketing strategy, impact factors, support factors, prospects, problems and e-retailing as an independent variables, step-wise two regression analysis has been used to find out the important predictors of the model. The results again support that the important factors like marketing strategy, prospects, and support, e-retailing. We have conducted regression analysis for two dependent variables preference of unorganised retail and performance of small retailers.

\section{Regression results for preference of unorganised retail by consumers}

Unorganised Retailing $=0.320 *$ Marketing strategy-0.325* Impact factors $+0.277^{*}$ Prospects $+0.340^{*}$ Support-0.109* Problems $+0.076^{*} \mathrm{E}-$ retailing

The results of the step-wise regression analysis depict that important factors of the model are:

Marketing strategy, prospects, support are important independent variables. Preference of unorganised retail are positively related to marketing strategy (.320), prospects (0.277), support (0.340) and e-retailing (0.241). ANOVA results depict that $\mathrm{F}=55.842,(\mathrm{p}<.001)$ is significant and thus the model is good (attached in appendix table 12,13,14,15). 


\section{Regression results for performance of retailers}

Performance of Retailers $=0.145^{*}$ Marketing strategy-0.308* Impact factors $+0.162 *$ Prospects $+0.028 *$ Support-0.013* Problems $+.229 * E-$ retailing

The results of the step-wise regression analysis depict that important factors of the model are:

Marketing strategy, prospects, support are important independent variables. Performance of small retailers are positively related to marketing strategy (.320), prospects (0.277), support (0.340) and e-retailing (0.241). ANOVA results depict that $\mathrm{F}=55.842,(\mathrm{p}<.001)$ is significant and thus the model is good (attached in appendix table 16,17,18,19).

\section{CONCLUSIONS}

\section{Major findings with Malaysia's perspective}

- Results of the study reveals that most of the consumers' spend more than RM 1500 on monthly spending on Food \& Grocery. Consumers prefers hypermarkets, convenience stores for purchase of fresh groceries like fruits, vegetables, and meat $\&$ dairy products and dry and branded groceries. Consumers do prefer mom $\mathrm{n}$ pop stores and traditional market due to its convenient location and operating hours. Consumers do prefer hypermarkets due to wide variety of brands available and online shopping facility

- Consumers prefers speciality stores for buying apparel $\mathrm{n}$ clothing. Least preferred option is traditional market for buying clothes due to lack of brands and quality.

- From results, it is evident that the product attributes like credit facility, proper display, proper packaging and variety of brands and store attributes like loyalty programs, trained sales personnel, air conditioned, home delivery, in store promotions \& cleanliness and availability of trolleys may be more important indicators of shopping from the emerging retail formats.

- Personal relationship with retailers, returns goods easily, loyalty to same vendor, home delivery are some of the attributes which consumers like to shop from unorganised retail.

- Results shows that consumers are aware about economic and social benefits of organised retail for the country. Consumers have given importance to factors like beneficial for farmers, economic growth and increase in income. Awareness about environmental safety, care 
about labour laws \& human rights and care about local culture are some social benefits.

- Most of respondents prefer organised retail due to the shopping online facility provided by organised retailers. Online security, user friendly, ease of navigation and quality of product are important attributes of e-retailing.

- FDI in organised retail are positively related to product attributes, store attributes, economic factors, social factors and e-retailing for both food $\mathrm{n}$ grocery and apparel $\mathrm{n}$ clothing.

- Retailer's marketing strategies are very important especially loyalty programmes, free gifts, store image and festival offers.

- Malaysian organised retailers like Mydin, Jaya Grocer and KK Supermart are the most famous big retailers.

- Retailers have given positive feedback on economic, social benefits of organised retailing. They think that there will be increase in jobs and standard of living if foreign retailers enter Malaysia. Most important benefit is increase in infrastructure and growth of real estate.

- Organised retailers give support to small retailers in terms of trainings, new market opportunities, quality assurance, technology support, contract farming, efficient marketing chain, better packaging and e-commerce.

- Some retailers still feel that big foreign retailers will create problems in their business. Various costs and need to comply with stringent quality are the two common problems faced by small retailers.

- Many retailers know about e-retailing and want to start e-commerce to attract customers.

- Preference of unorganised retail are positively related to marketing strategy adopted by small retailers, prospects of FDI, support from foreign retailers and e-retailing preferred by consumers.

- Performance of small retailers are positively related to marketing strategy, prospects, support and e-retailing.

\section{DISCUSSIONS}

Malaysian consumers' are conscious of quality and looking for diverse product range, so will visit organised retail format for shopping food and groceries and apparel \& clothing. These stores are highly conscious about quality and offer product diversity. Consumers are also looking for additional facilities like parking facilities, trained sales personal and nice in store 
promotion, shopping experience enhancer attributes, these will be provided by organised retail format. Malaysian consumers also prefer to shop from traditional market due to personal relationship with retailers, returns goods easily, home delivery types of the attributes. Consumers have compared services of organised Malaysian retailers and foreign retailers as compare to traditional market, results are in favour of FDI in new retail formats. Now a days, consumers visit organised retail formats not for shopping only but for enjoying food courts and entertainment also. So organised retailers and malls owners should focus upon food courts, restaurants and entertainment facilities for consumers like food court, children play area, clean wash rooms, decoration of malls on special occasions etc. These strategies will help organised retailers to keep customers satisfied and delighted to enjoy shopping and visit again. Consumers are fully aware of economic, social, technological benefits of FDI in organised retailing and support government initiatives to promote FDI in retailing.

Retailers should focus on marketing strategies such as loyalty programmes, free gifts, store image and festival offers to attract customers as compare to organised retail. It is found from the study that there will be increase in jobs and increase in standard of living if foreign retailers increase their business in Malaysia. Retailers should feel positive about the prospects of organised retail in terms of important benefit to farmers, growing awareness of consumers. Foreign retailers can also help small traditional retailers by trainings, new market opportunities, quality assurance, technology support, contract farming, efficient marketing chain, better packaging and e-commerce. Retailers are aware of e-retailing and are keen to start e-commerce website to attract customers. Study has revealed that small retailers business will not be affected by FDI as consumers prefers both retail formats and government is supporting small retail business with strict rules and regulations for FDI. There can be some problems to be faced by retailers like late payment and difficulty in consistent supply but these issues can be addressed by the Government. Consumers preference of unorganised retail and performance of traditional retailers will influenced by marketing strategies adopted by traditional retailers, prospects of FDI, support from foreign retailers and e-retailing preferred by consumers.

Malaysian government has made many rules and regulations for promoting entry of foreign retailers to boost up economy and help small retailers business. As government officials know that consumers prefer both foreign retailers and small retailers and they support benefits of FDI in organised retailing. Government presently is supporting small retail business with special programmes for bumiputera retailers and these are real success. Government can made special initiatives for foreign retailers to follow on compliance with contracts by both retailers and suppliers; equal treatment 
among suppliers; prompt payment; and cooperation in logistics development. They can also help farmers in procurement, using new technologies, logistics efficiency, and forming the strategies of their active participation in different market channels. These policies will help Malaysia to have win- win position for foreign and small retailers.

\section{REZIME \\ UTICAJ SDI U ORGANIZOVANOJ MALOPRODAJI U MALEZIJI: STUDIJA RAZLIČITIH POSREDNIKA}

Ova studija ispituje uticaj stranih direktnih investicija (SDI) u oblasti organizovane maloprodaje u Maleziji sa osvrtom na odnos potrošača i trgovaca na malo. Istraživanje pokazuje da su SDI u organizovanoj maloprodaji prehranbenih proizvoda, odeće kao i robe široke potrošnje povezani sa brendovima, karakteristikama prodavnica, ekonomskim, društvenim i tehnološkim koristima koje SDI omogućavaju kako potrošačima tako i trgovcima na malo. Malezijski potrošači koji su svesni kvaliteta proizvoda i traže širok asortiman proizvoda radije će obaviti kupovinu u organizovanom maloprodajnom objektu. Potrošači su svesni ekonomskih, društvenih i tehnoloških prednosti SDI $u$ organizovanoj maloprodaji. Predložene su i marketing strategije maloprodajnih subjekata kao što su programi lojalnosti, besplatni pokloni, brendiranje prodavnica i festivalske ponude kako bi se privukli kupci organizovanim maloprodajama. Pored toga, ovaj rad empirijski ispituje kako strani trgovci na malo mogu pomoći malim tradicionalnim maloprodavcima putem obuka, predstavljanja novih tržišnih mogućnosti, osiguranja kvaliteta, tehnološke podrške, ugovaranja, efikasnog marketing lanca, boljeg pakovanja i e-trgovine. Kao i njihovu pomoć malim poljoprivrednicima u stvaranju kapaciteta za nastavak uspešnih strategija portfolija ali i mogućnostima učešća u različitim tržišnim kanalima.

Ključne reči: Strane direktne investicije SDI, organizovana maloprodaja, ekonomske koristi, društvene koristi, tehnološke koristi

\section{REFERENCES}

1. Abdullah, A., Arshad, F., \& Latif, I. (2011). The impact of supermarkets and hypermarkets from the perspectives of fresh fruit and vegetable (FFV) wholesalers and retailers. Journal of Agribusiness Marketing, 4, 21-37.

2. Ahmad, A., Rahman, I., Sallehuddin, N., Jumaat,M., Che,W., \& Ahmad,O. (2008). Small Retailers and Entreprenuers perceptions on the 
Departmental Store Development: A Malaysian Case Study. International Review of Business Research Papers, 4, 1, 1-10.

3. Chamhuri, N., Batt, P. (2013). Exploring the factors influencing consumer's choice of retail store when purchasing fresh meat in Malaysia. Journal of Retailing and Consumer Services, 516-528.

4. Chamhuri, N., Batt, P. (2013). Exploring the factors influencing consumer's choice of retail store when purchasing fresh meat in Malaysia. Journal of Retailing and Consumer Services, 516-528.

5. Chan, P., Finnegan, C., \& Sternquist, B. (2011). Country and firm level factors in international retail expansion. European Journal of Marketing, 45, 6, 1005-1022.

6. Fauziah,S. A., Ihtiyar, A., \& Omar, R. (2014). A Comparative Study on Service Quality in the Grocery Retailing: Evidence from Malaysia and Turkey. Procedia - Social and Behavioral Sciences, 109, 763 - 767.

7. Feeny, A., Vongpatanisn, T., \& Soonsatham, A. (1996). Retailing in Thailand. International Journal of Retail \& Distribution Management, 24, 8, 38-44.

8. Gaiha, R., \& Thapa, G. (2007). Supermarkets, Smallholders and Livelihoods Prospects in Selected Asian Countries, ASARC.

9. Goldman, A. (2001). The transfer of retail formats into developing economies: The example of China. Journal of Retailing, 77, 221-242.

10. Gorton, M., Saue, J., \& Supatpongkul, P. Wet Markets, Supermarkets and the "Big Middle" for Food Retailing in Developing Countries: Evidence from Thailand. World Development 39, 9, 1624-1637.

11. Guthrie, J., Guthrie, A., \& Lawson, R. (2006). Farmers' markets: the small business counter-revolution in food production and retailing. British Food Journal, 108, 7, 560-573.

12. Guy, C., \& Bennison, D. (2002). Retail planning policy, superstore development and retailer competition. International journal of retail \& distribution management, 30.

13. Hassan, H., Sade, A., \& Rahman, S. (2013). Malaysian hypermarket retailing development and expansion. International Journal of Retail \& Distribution Management, 41, 8, 584-595.

14. Kaliappan,S., Alavi,R., Abdullah, \& Arif, Z. (2008). Spillover effects of foreign hypermarkets on domestic suppliers in Malaysia. International Journal of Retail \& Distribution Management, 37, 3, 226-249.

15. Kaliappan, S., Alavi, R., Abdullah, K., \& Zakaullah,A. (2008). Liberalization of Retail Sector and the Economic Impact of the Entry of Foreign Hypermarkets on Local Retailers in Klang Valley, Malaysia. Int. Journal of Economics and Management, 2, 2, 323 - 342. 
16. Kamarulzaman, Y., Lih, C. (2010). Attracting Shoppers to Shopping Malls: The Malaysian Perspective. Interdisciplinary journal of contemporary research in business, 2,3 .

17. Kittichai, W., \& Chompunuch, P. (2011). A comparative investigation of consumers' attitudes toward marketing practices of hypermarket retailers in Thailand. International Journal of Retail \& Distribution Management, 39, 9, 702-720.

18. Krishnamoorthy, B., Mazumdar, S., \& Mohanty, C. (2013). Growth of Future Group logistics - Indian retail company, Competitiveness Review, $23,4 / 5,330-342$.

19. Kumar, S. (2008). A study of the supermarket industry and its growing logistics capabilities. International Journal of Retail \& Distribution Management, 36, 3, 192-211.

20. Kumar, K., \& Rahman (2013). Measuring shopping values of Malaysian retail consumers. Asia pacific journal of marketing and logistics, 25, 200224.

21. Lo, W.C., Lau, H.F., \& Lin, G.S. (2001). Problem n Prospects of supermarket development in China. International Journal of retail $n$ distribution management, 29, 2, 66-75.

22. Miranda, J.M., \& Jegasothy, K. (2008). Malaysian grocery shoppers' behavioural response to stock-outs. Asia Pacific Journal of Marketing and Logistics, 20, 4, 396-412.

23. Moustier, P., Tam, P., Anh, D., Binh, V., \& Loc, N. (2010). The role of farmer organizations in supplying supermarkets with quality food in Vietnam. Food Policy 35, 69-78.

24. Mui, L., Badarulzaman, N., Ahmad, G. (2003). Retail Activity in Malaysia: From Shophouse to Hypermarket, University of Queensland and Queensland University of Technology, Brisbane, Australia.

25. Mutebi, \& Alex, M. (2007) .Regulatory Responses to Large-format Transnational Retail in South-east Asian Cities. Urban Studies, 44, 2, 357-379.

26. Narrod, C., Roy, D., Okello, J., Avendano, B., Rich, K., \& Thorat, A., Int. journal of food policy Elsevier.

27. Nicholas, A., Hayley, M. (1999). European retail expansion in South East Asia, European Business Review, 99, 2, 91-104.

28. Reardon, T., \& Hopkins, R. (2006). The Supermarket Revolution in Developing Countries: Policies to Address Emerging Tensions among Supermarkets, Suppliers and Traditional Retailers. The European Journal of Development Research, 18, 4, 522-545.

29. Ruerd, R., Dave, B., \& Hualiang, L. (2007). Vegetable procurement by Asian supermarkets: a transaction cost approach, Supply Chain Management. An International Journal, 12, 1, 60-68. 
30. Tinggi, Jakpar, \& Padang (2012). Are Malaysian Bumiputera Grocery Retails Still Relevant? Consumers' Perpective in Sarawak. International Journal of Business and Social Science, 3, 8 .

31. Tinggi, M., Jakpar, S., \& Padang, S. (2012). Are Malaysian bumiputera grocery retails still relevant? Consumer's perspective in Sarawak. International journal of business and social science, 3,8 .

32. Yanee, S., Jayant, R. (2012). The fruit and vegetable marketing chains in Thailand: policy impacts and implications. International Journal of Retail \& Distribution Management, 40, 9, 656-675.

\section{LIST OF TABLES \& FIGURES}

\begin{tabular}{|l|l|l|}
\hline Sr.No. & \multicolumn{1}{|c|}{ Table No. } & \multicolumn{1}{c|}{ Table Description } \\
\hline 1 & Table 1 & Global Retail Development Index (sources: AT Kearney report 2014) \\
\hline 2 & Table 2 & Basic data of selected economies in the Asia Pacific region, 2012 \\
\hline 3 & Table 3 & Retail sales of selected economies in the Asia Pacific region, 2013 \\
\hline 4 & Table 4 & Regression analysis for food \& grocery in Malaysia \\
\hline 5 & Table 5 & Model summary food \& grocery in Malaysia \\
\hline 6 & Table 6 & Anova test food \& grocery in Malaysia \\
\hline 7 & Table 7 & Coefficients food \& grocery in Malaysia \\
\hline 8 & Table 8 & Regression Analysis for Apparel \& clothing \\
\hline 9 & Table 9 & Model Summary apparel \& clothing in Malaysia \\
\hline 10 & Table 10 & Anova Test apparel \& clothing in Malaysia \\
\hline 11 & Table 11 & Coefficients Apparel \& clothing in Malaysia \\
\hline 12 & Table 12 & Regression Analysis for retailers in Malaysia \\
\hline 13 & Table 13 & Model summary unorganised retail \\
\hline 14 & Table 14 & Anova summary unorganised retail \\
\hline 15 & Table 15 & Coefficients unorganised retail \\
\hline 16 & Table 16 & Regression Analysis for retailers in Malaysia \\
\hline 17 & Table 17 & Model summary performance of retailers \\
\hline 18 & Table 18 & Anova performance of retailers \\
\hline 19 & Table 19 & Coefficients performance of retailers \\
\hline 20 & Figure 1 & Impact of FDI on organised retail \\
\hline
\end{tabular}

\section{APPENDIX}

Table 1: Global Retail Development Index (sources: AT Kearney report 2014)

\begin{tabular}{|l|l|l|l|l|l|}
\hline Country & $\begin{array}{l}\text { Market Attractiveness } \\
(25 \%)\end{array}$ & $\begin{array}{l}\text { Country } \\
\text { Risk }(25 \%)\end{array}$ & $\begin{array}{l}\text { Market Saturation } \\
(25 \%)\end{array}$ & $\begin{array}{l}\text { Time Pressure } \\
(25 \%)\end{array}$ & $\begin{array}{l}\text { GRDI } \\
\text { score }\end{array}$ \\
\hline Chile & 100.0 & 100.0 & 13.2 & 47.3 & 65.1 \\
\hline China & 60.9 & 52.5 & 44.5 & 100.0 & 64.4 \\
\hline UAE & 98.5 & 82.3 & 17.5 & 43.8 & 60.5 \\
\hline Brazil & 99.4 & 59.8 & 48.7 & 33.2 & 60.3 \\
\hline Malaysia & 66.7 & 68.7 & 32.2 & 43.5 & 52.8 \\
\hline Turkey & 83.6 & 50.2 & 46.5 & 30.2 & 52.6 \\
\hline Russia & 94.0 & 38.4 & 30.7 & 46.4 & 52.4 \\
\hline Indonesia & 46.2 & 33.4 & 57.7 & 59.6 & 49.2 \\
\hline Sri Lanka & 6.3 & 36.7 & 78.8 & 67.3 & 47.3 \\
\hline Nigeria & 39.6 & 6.6 & 92.3 & 48.0 & 46.6 \\
\hline
\end{tabular}




\begin{tabular}{|l|l|l|l|l|l|}
\hline India & 26.4 & 39.0 & 72.3 & 43.4 & 45.3 \\
\hline Philippines & 33.0 & 33.2 & 55.8 & 50.5 & 43.1 \\
\hline Vietnam & 3.8 & 21.9 & 75.0 & 55.7 & 39.1 \\
\hline
\end{tabular}

Table 2: Basic data of selected economies in the Asia Pacific region, 2012

\begin{tabular}{|l|l|l|l|}
\hline & $\begin{array}{l}\text { Population } \\
\text { (million) }\end{array}$ & Real GDP growth (\%) & $\begin{array}{l}\text { Consumer } \\
\text { inflation (av. \%) }\end{array}$ \\
\hline China & $1,344.6$ & 7.7 & 2.6 \\
\hline Japan & 126.1 & 1.4 & 0.0 \\
\hline South Korea & 50.0 & 2.0 & 2.2 \\
\hline Taiwan & 23.3 & 1.5 & 1.9 \\
\hline Thailand & 66.8 & 6.5 & 3.0 \\
\hline Malaysia & 29.2 & 5.6 & 1.7 \\
\hline Singapore & 5.3 & 1.3 & 4.6 \\
\hline Asia \& Australasia & $3,758.1$ & 4.0 & 3.3 \\
\hline
\end{tabular}

Source: Economist Intelligence unit

Table 3: Retail sales of selected economies in the Asia Pacific region, 2013

\begin{tabular}{|l|l|l|l|l|l|}
\hline & $\begin{array}{l}\text { Retail Sales ( } \\
\text { US\$ billon) }\end{array}$ & $\begin{array}{l}\text { Yoy growth } \\
(\%)\end{array}$ & $\begin{array}{l}\text { Internet } \\
\text { sales(US\$ } \\
\text { billion) }\end{array}$ & $\begin{array}{l}\text { Yoy growth } \\
(\%)\end{array}$ & $\begin{array}{l}\text { Share of Internet } \\
\text { sales in retail } \\
\text { sales (\%) }\end{array}$ \\
\hline China & $1,791.1$ & 11.0 & 100.3 & 43.4 & 5.6 \\
\hline Japan & $1,021.5$ & 0.7 & 42.7 & 9.6 & 4.2 \\
\hline South Korea & 222.7 & 3.3 & 28.8 & 10.0 & 12.9 \\
\hline Taiwan & 92.2 & 2.7 & 6.5 & 11.0 & 7.0 \\
\hline Thailand & 80.8 & 6.1 & 0.8 & 18.0 & 1.0 \\
\hline Malaysia & 51.5 & 3.8 & 0.4 & 14.4 & 0.7 \\
\hline Singapore & 24.6 & 4.7 & 0.8 & 12.3 & 3.1 \\
\hline
\end{tabular}

Source: Economist Intelligence Unit

Table 4: Regression analysis for food \& grocery in Malaysia

\begin{tabular}{|l|l|l|l|}
\hline Hypothesis & Coefficients & $\mathrm{p}$ value & Results \\
\hline Product Attributes & 0.345 & $\mathrm{p}<0.1$ & Supported \\
\hline Store Attributes & 0.154 & $\mathrm{p}<0.1$ & Supported \\
\hline Economic Factors & 0.113 & $\mathrm{p}>0.1$ & Not supported \\
\hline Social Factors & 0.084 & $\mathrm{p}>0.1$ & Not Supported \\
\hline E-retailing & 0.232 & $\mathrm{p}<0.1$ & supported \\
\hline
\end{tabular}

Table 5: Model summary food \& grocery in Malaysia

\section{Model Summary ${ }^{b}$}

\begin{tabular}{|l|l|r|r|r|r|}
\hline Model & R & R Square & Adjusted R Square & Std. Error of the Estimate & Durbin-Watson \\
\hline 1 & $.767^{\mathrm{a}}$ & .588 & .577 & .64984897 & 2.016 \\
\hline
\end{tabular}

a. Predictors: (Constant), E-Retailing, Food nGroceryStore Attributes, FDI-Social Factors, Food \& Grocery PA, FDI-Economic Factors

b. Dependent Variable: Organised Retail-Groceries

Table 6: Anova test food \& grocery in Malaysia

ANOVA ${ }^{a}$

\begin{tabular}{|ll|r|r|r|r|r|}
\hline Model & & Sum of Squares & df & Mean Square & \multicolumn{1}{|c|}{ F } & Sig. \\
\hline 1 & Regression & 117.911 & 5 & 23.582 & 55.842 & $.000^{\mathrm{b}}$ \\
& Residual & 82.772 & 196 & .422 & & \\
& Total & 200.682 & 201 & & & \\
\hline
\end{tabular}


a. Dependent Variable: Organised Retail-Groceries

b. Predictors: (Constant), E-Retailing, Food nGroceryStore Attributes, FDI-Social Factors, Food \& Grocery PA, FDI-Economic Factors

Table 7 : Coefficients food \& grocery in Malaysia

\section{Coefficients $^{\mathrm{a}}$}

\begin{tabular}{|c|c|c|c|c|c|}
\hline \multirow[b]{2}{*}{ Model } & \multicolumn{2}{|c|}{ Unstandardized Coefficients } & \multirow{2}{*}{$\frac{\text { Standardized Coefficients }}{\text { Beta }}$} & \multirow[b]{2}{*}{$\mathrm{t}$} & \multirow[b]{2}{*}{ Sig. } \\
\hline & B & Std. Error & & & \\
\hline 1 (Constant) & .003 & .046 & & .073 & .942 \\
\hline Food \& Grocery PA & .345 & .081 & .345 & 4.285 & .000 \\
\hline Food nGroceryStore Attributes & .154 & .077 & .155 & 2.019 & .045 \\
\hline FDI-Economic Factors & .113 & .081 & .113 & 1.398 & .164 \\
\hline FDI-Social Factors & .084 & 076 & .083 & 1.097 & .274 \\
\hline E-Retailing & 232 & 058 & .233 & 3.999 & .000 \\
\hline
\end{tabular}

a. Dependent Variable: Organised Retail-Groceries

Table 8: Regression Analysis for Apparel \& clothing

\begin{tabular}{|l|l|l|l|}
\hline Hypothesis & Coefficients & $\mathrm{p}$ value & Results \\
\hline Product Attributes & 0.345 & $\mathrm{p}<0.1$ & Supported \\
\hline Store Attributes & 0.154 & $\mathrm{p}<0.1$ & Supported \\
\hline Economic Factors & 0.113 & $\mathrm{p}>0.1$ & Not supported \\
\hline Social Factors & 0.084 & $\mathrm{p}>0.1$ & Not Supported \\
\hline E-retailing & 0.232 & $\mathrm{p}<0.1$ & supported \\
\hline
\end{tabular}

Table 9: Model Summary apparel \& clothing in Malaysia

\begin{tabular}{|l|l|r|r|r|}
\hline Model & R & R Square & Adjusted R Square & Std. Error of the Estimate \\
\hline 1 & $.631^{\mathrm{a}}$ & .398 & .382 & .78581196 \\
\hline
\end{tabular}

a. Predictors: (Constant), Apparel Store Attributes, FDI-Social Factors, E-Retailing, FDI-Economic Factors, Apparel Product Attributes

Table 10: Anova Test apparel \& clothing in Malaysia ANOVA ${ }^{\mathbf{a}}$

\begin{tabular}{|ll|r|r|r|r|r|}
\hline Model & & Sum of Squares & df & Mean Square & F & Sig. \\
\hline 1 & Regression & 80.352 & 5 & 16.070 & 26.025 & $.000^{\mathrm{b}}$ \\
& Residual & 121.648 & 197 & .618 & & \\
& Total & 202.000 & 202 & & & \\
\hline
\end{tabular}

a. Dependent Variable: Organised Retail Apparel 2

b. Predictors: (Constant), Apparel Store Attributes, FDI-Social Factors, E-Retailing, FDI-Economic Factors, Apparel Product Attributes

Table 11: Coefficients Apparel \& clothing in Malaysia Coefficients ${ }^{\mathbf{a}}$

\begin{tabular}{|c|c|c|c|c|c|}
\hline \multirow[b]{2}{*}{ Model } & \multicolumn{2}{|c|}{ Unstandardized Coefficients } & \multirow{2}{*}{$\begin{array}{c}\begin{array}{c}\text { Standardized } \\
\text { Coefficients }\end{array} \\
\text { Beta }\end{array}$} & \multirow[b]{2}{*}{$\mathrm{t}$} & \multirow[b]{2}{*}{ Sig. } \\
\hline & $\mathrm{B}$ & Std. Error & & & \\
\hline $1 \quad$ (Constant) & $-6.579 \mathrm{E}-16$ & .055 & & .000 & 1.000 \\
\hline FDI-Economic Factors & .179 & .096 & .179 & 1.854 & .065 \\
\hline FDI-Social Factors & .212 & .092 & .212 & 2.306 & .022 \\
\hline E-Retailing & .213 & .070 & .213 & 3.053 & .003 \\
\hline Apparel Product Attributes & -.071 & .126 & -.071 & -.564 & .574 \\
\hline Apparel Store Attributes & .232 & .126 & .232 & 1.843 & .067 \\
\hline
\end{tabular}

a. Dependent Variable: Organised Retail Apparel 2 
Table 12: Regression Analysis for retailers in Malaysia

\begin{tabular}{|l|l|l|l|}
\hline Hypothesis & Coefficients & $\mathbf{p}$ value & Results \\
\hline Marketing Strategy & 0.320 & $\mathrm{p}<0.1$ & Supported \\
\hline Impact Factors & -0.325 & $\mathrm{p}>0.1$ & Not Supported \\
\hline Prospects & 0.277 & $\mathrm{p}<0.1$ & supported \\
\hline Support & 0.340 & $\mathrm{p}<0.1$ & Supported \\
\hline Problems & -0.109 & $\mathrm{p}<0.1$ & supported \\
\hline E-retailing & 0.076 & $\mathrm{p}>0.1$ & Not supported \\
\hline
\end{tabular}

Table 13: Model summary unorganised retail

\section{Model Summary}

\begin{tabular}{|l|r|r|r|r|}
\hline Model & \multicolumn{1}{|c|}{ R } & R Square & Adjusted R Square & Std. Error of the Estimate \\
\hline 1 & $.679^{\mathrm{a}}$ & .588 & .577 & .80340273 \\
\hline
\end{tabular}

a. Predictors: (Constant), Eretailing, Problems, Support, Impact Factors, Marketing Strategy, Prospects

Table 14: Anova summary unorganised retail

ANOVA ${ }^{\mathrm{a}}$

\begin{tabular}{|ll|r|r|r|c|c|}
\hline Model & & Sum of Squares & \multicolumn{1}{|c|}{ df } & Mean Square & F & Sig. \\
\hline 1 & Regression & 3.599 & 6 & .600 & 55.45 & $.000^{\mathrm{b}}$ \\
& Residual & 27.755 & 43 & .645 & & \\
& Total & 31.353 & 49 & & & \\
\hline
\end{tabular}

a. Dependent Variable: Unorganised Retail

b. Predictors: (Constant), Eretailing, Problems, Support, Impact Factors, Marketing Strategy, Prospects

Table 15: Coefficients unorganised retail

Coefficients $^{\mathbf{a}}$

\begin{tabular}{|c|c|c|c|c|c|}
\hline \multirow[b]{2}{*}{ Model } & \multicolumn{2}{|c|}{ Unstandardized Coefficients } & \multirow{2}{*}{$\begin{array}{c}\text { Standardized Coefficients } \\
\text { Beta }\end{array}$} & \multirow[b]{2}{*}{$\mathrm{t}$} & \multirow[b]{2}{*}{ Sig. } \\
\hline & $\mathrm{B}$ & Std. Error & & & \\
\hline $1 \quad$ (Constant) & .191 & .114 & & 1.682 & .100 \\
\hline Marketing Strategy & .256 & .206 & .320 & 1.246 & .000 \\
\hline Impact Factors & .260 & .191 & -.325 & -1.361 & .181 \\
\hline Prospects & .221 & .254 & .277 & .873 & .004 \\
\hline Support & .272 & .187 & .340 & 1.458 & .002 \\
\hline Problems & -.087 & .148 & -.109 & -.586 & .000 \\
\hline Eretailing & .061 & .254 & .076 & .241 & .811 \\
\hline
\end{tabular}

a. Dependent Variable: Unorganised Retail

Table 16: Regression Analysis for retailers in Malaysia

\begin{tabular}{|l|l|l|l|}
\hline Hypothesis & Coefficients & $\mathbf{p ~ v a l u e}$ & Results \\
\hline Marketing Strategy & 0.145 & $\mathrm{p}<0.1$ & Supported \\
\hline Impact Factors & -0.308 & $\mathrm{p}>0.1$ & Not Supported \\
\hline Prospects & 0.162 & $\mathrm{p}<0.1$ & supported \\
\hline Support & 0.028 & $\mathrm{p}<0.1$ & Supported \\
\hline Problems & -0.013 & $\mathrm{p}>0.1$ & Not supported \\
\hline E-retailing & .229 & $\mathrm{p}<0.1$ & supported \\
\hline
\end{tabular}

Table 17: Model summary performance of retailers

Model Summary

\begin{tabular}{|l|r|r|r|r|}
\hline Model & \multicolumn{1}{|c|}{ R } & R Square & Adjusted R Square & Std. Error of the Estimate \\
\hline 1 & $.713^{\mathrm{a}}$ & .667 & .039 & .98028012 \\
\hline
\end{tabular}

a. Predictors: (Constant), Eretailing, Problems, Impact Factors, Support, Prospects, Marketing Strategy 
Table 18:Anova performance of retailers

ANOVA ${ }^{\mathrm{a}}$

\begin{tabular}{|ll|r|r|r|r|r|}
\hline Model & & Sum of Squares & df & Mean Square & F & Sig. \\
\hline 1 & Regression & 9.710 & 6 & 1.618 & 54.87 & $.001^{\mathrm{b}}$ \\
& Residual & 91.290 & 95 & .961 & & \\
& Total & 101.000 & 101 & & & \\
\hline
\end{tabular}

a. Dependent Variable: performance of retail store

b. Predictors: (Constant), Eretailing, Problems, Impact Factors, Support, Prospects, Marketing Strategy

Table 19: coefficients performance of retailers

Coefficients $^{\mathrm{a}}$

\begin{tabular}{|c|c|c|c|c|c|}
\hline \multirow[b]{2}{*}{ Model } & \multicolumn{2}{|c|}{ Unstandardized Coefficients } & \multirow{2}{*}{$\frac{\text { Standardized Coefficients }}{\text { Beta }}$} & \multirow[b]{2}{*}{$\mathrm{t}$} & \multirow[b]{2}{*}{ Sig. } \\
\hline & $\mathrm{B}$ & Std. Error & & & \\
\hline $1 \quad$ (Constant) & .009 & .098 & & .092 & .927 \\
\hline Marketing Strategy & -.146 & .155 & .14 & .946 & .004 \\
\hline Impact Factors & .303 & .129 & -.30 & 2.344 & .021 \\
\hline Prospects & -.178 & .166 & .16 & 1.071 & .007 \\
\hline Support & .028 & .134 & .02 & .210 & .000 \\
\hline Problems & -.013 & .108 & -.01 & -.118 & .907 \\
\hline Eretailing & .230 & .157 & .22 & 1.466 & .146 \\
\hline
\end{tabular}

a. Dependent Variable: performance of retail store

Figure: 1 Impact of FDI on organised retail

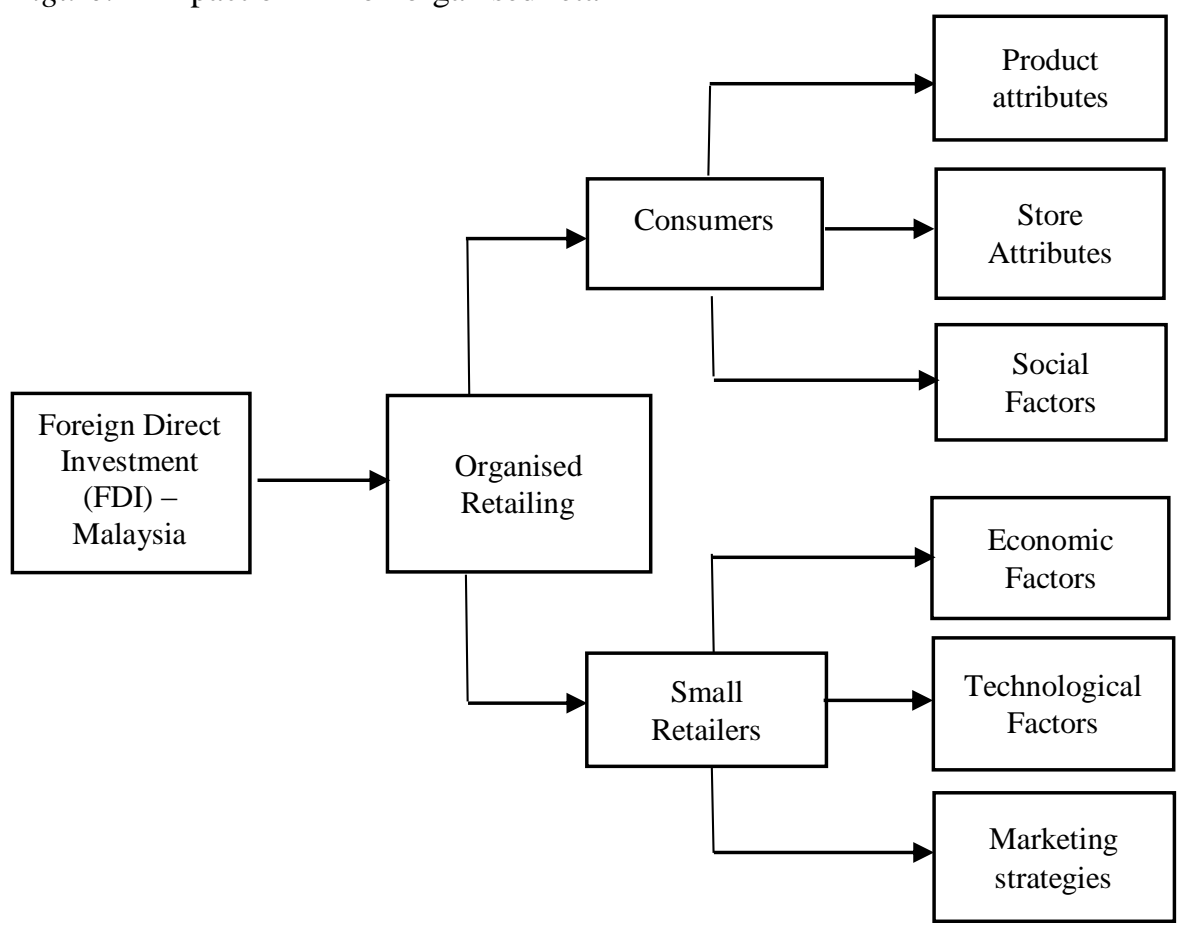

Ovaj rad je primljen 03.02.2017., a na sastanku redakcije časopisa prihvaćen za štampu 23.09.2017. godine. 